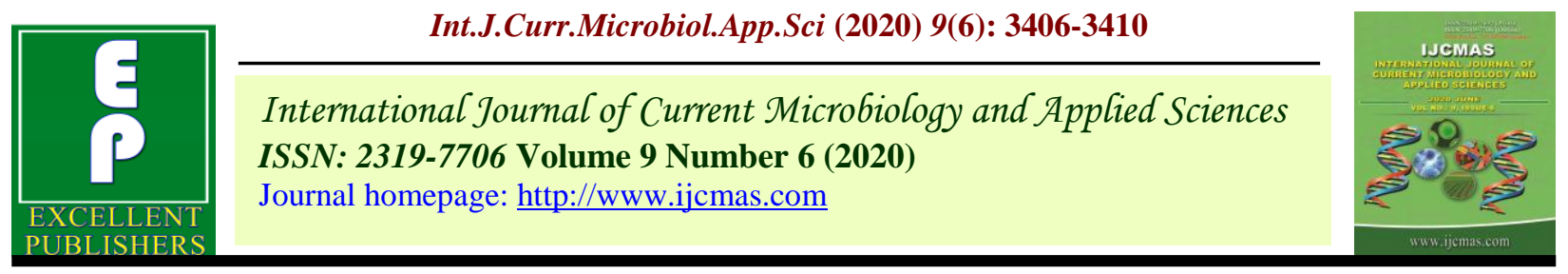

Original Research Article

https://doi.org/10.20546/ijcmas.2020.906.403

\title{
Cost of Cultivation of Tomato Crop in Durg District of Chhattisgarh, India
}

\author{
Anjali Verma ${ }^{1^{*}}$, B.C. Jain ${ }^{2}$, Shashank Sharma ${ }^{3}$ and Yogesh Kumar $\mathrm{Sai}^{4}$ \\ ${ }^{1}$ Department of Agri-Business \& Rural Management, ${ }^{2}$ Department of Agricultural Economics, \\ College of Agriculture, IGKV, Raipur, (CG) \\ *Corresponding author
}

\begin{tabular}{|l|}
\hline K e y w o r d s \\
Total production, \\
$\begin{array}{l}\text { Cost of cultivation, } \\
\text { Input-output ratio }\end{array}$ \\
\hline Article Info \\
\hline $\begin{array}{l}\text { Accepted: } \\
\text { 26 May } 2020 \\
\text { Available Online: } \\
\text { 10 June } 2020\end{array}$ \\
\hline
\end{tabular}

\section{A B S T R A C T}

Tomato is rich source of vitamins A, C, Potassium, Minerals and Fibers. Tomatoes are used in the preparation of soup, salad, pickles, ketchup, puree and sauces and also consumed as a vegetable in many other ways. In Chhattisgarh, total production of tomato is 868.60 ('000) MT from an area of about 52.89 ('000) Ha. (Joint director horticulture, 2017-18). The major tomato producing districts are Raipur, Durg, Bastar, Jashpur and Bilaspur. Fourty farmers were selected purposively from four villages i.e. Banbarad, Aheri and Baghdumar. Five wholesalers and seven retailers were also selected for the fulfilment of the objectives. The primary data were collected for year 2018-19. On an average cost of cultivation per hectare of tomato was found to be Rs 168023.6. The average cost of production per quintal of tomato was worked out to be Rs.360.4864. The input-output ratio of tomato was found to be1:1.71 at sample farms.

\section{Introduction}

Tomato (Lycopersicon esculentum) belongs to the genus Lycopersicon under Solanaceae family. Tomato is rich source of vitamins A, $\mathrm{C}$, potassium, minerals and fibers. Tomato is one of the most important protective food crops of India. India ranks second in the area as well as production of tomato next to China. Tomato production is expected to be 19.33 million tonnes, up 1.68 per cent, compared to 19.01 million tonnes in 2018-19.Total horticulture production in the country stood at
310.74 million tonnes in $2018-19$, as per final estimates released by the ministry of agriculture and farmers welfare. This is marginally higher than the horticulture production in 2017-18.

In Chhattisgarh, total production of tomato is 868.60 ('000) MT from an area of about 52.89 ('000) Ha. Chhattisgarh accounts for about $4.98 \%$ of the total production of Tomato in the country. The productivity of tomato crop in Chhattisgarh is $16.42 \mathrm{MT} / \mathrm{Ha}$. which is found lower to all India average of 
21.99 MT/Ha. The major tomato producing districts are Raipur, Durg, Bastar, Balod and Jaspur. In Chhattisgarh, total production of tomato is $11,33,435 \mathrm{MT}$ from an area of about 64,681 Ha (2017-18). The major tomato producing districts are Raipur, Durg, Bastar, Balod and Jaspur.

\section{Materials and Methods}

The study was confined to Durg district of Chhattisgarh state because tomato was grown in both Kharif \& Rabi seasons. Out of three blocks of the district, Dhamdhablock was selected purposively. The list of tomato growers was obtained from the District director horticulture, Durg. From the list of 231 tomato growers 18 per cent tomato growers were considered and proportionate to their percentages as per the farm size of holdings. Therefore 40 tomato growers were looking to the responses for the study. This comprised of 4 tomato growers for marginal farms, 14 for small farms, 17 for medium farms and 5 for large farms, respectively.

The simple averages and percentage statistical tools were applied to analyze the data and report the results/ outcomes of the study.

Input output ratio $=$ Gross income $/$ Total cost . Benefit-cost $=$ Net income $/$ Total cost .

\section{Results and Discussion}

The cost of cultivation of tomato of sampled farms is worked out in Rs/ha and presented in Table 1. It clearly shows that the cost of cultivating tomato per hectare in large farms was higher than in marginal farms. Overall the cultivation cost per hectare of tomato has been found to be Rs per 168023.6 hectare on average. The cultivation costs were higher for large farms (Rs.188694.5 / ha) compared to marginal farms (Rs. 119031.1 / ha), small (Rs. 150994.9 / ha.) and medium farms (Rs. 169410.5/ha.). Cost of cultivation per hectare showed an upward trend with the rise in farm size. It was because the large farmers incurred more expenditure on modern farm inputs such as quality seed, fertilizer, plant protection material, hired labour, etc. as a result of borrowing from credit institutions and strengthened economic status compared to marginal, small and medium-sized farmers.

Yield, value of output and cost of production per quintal

The yield, value of output per hectare and cost of production per quintal of tomato on the sampled farms have been worked out in Table 2. This indicates that the average yield per hectare of tomato was 466.1025 quintals of the sampled farms. Average cost of production of tomato was worked out in Rs/q and found to be Rs.360.4864 irrespective to the farm size. While it was the maximum under marginal farms (Rs.378.5736) followed by small farms (Rs.353.9828), medium farms (Rs.341.0789) and large farms (Rs. 321.5982).

It is interesting to note that marginal and small farms earned more on per rupee investment. It was due to better management of farm and crop by marginal and small farms than that of large farms. The average value of output per hectare came to Rs.372882. The higher value of output on large farms was associated with the higher expenditure incurred on modern farm inputs.

\section{Profitability in tomato cultivation}

The net income, input-output ratio and benefit:cost ratio was worked out in Rs/ha by farm size of holding and presented in Table 3. It revealed that irrespective to the farms size, the net income earned by farmers was Rs/ha204858.4. The input-output ratio was found to be 1:1.71 and benefit of Rs 2.21 in 
per rupee investment on tomato cultivation. The net income earned by farmers was found to be increasing with farm size of holding and ranging from Rs.132504.9to Rs. 280697.5 of marginal to large farm size of holdings. The similar pattern of input- output and B: C ratio had also been noticed with respect to farm size of holding.

Table.1 Economics of tomato on sampled farm

\begin{tabular}{|c|c|c|c|c|c|c|}
\hline \multirow{3}{*}{ S.No } & \multirow{3}{*}{\begin{tabular}{|l} 
Particular \\
A. Variable cost \\
\end{tabular}} & \multirow{2}{*}{\multicolumn{5}{|c|}{ Farm size }} \\
\hline & & & & & & \\
\hline & & Marginal & Small & Medium & Large & 0verall \\
\hline 1 & Family labour & $\begin{array}{l}34064 \\
(28.62)\end{array}$ & $\begin{array}{l}24604 \\
(16.29)\end{array}$ & $\begin{array}{l}12200 \\
(7.2)\end{array}$ & $\begin{array}{l}6400 \\
(3.39)\end{array}$ & $\begin{array}{l}14421.45 \\
(8.58)\end{array}$ \\
\hline 2 & Hired human labour & $\begin{array}{l}24000 \\
(20.16)\end{array}$ & $\begin{array}{l}36000 \\
(23.84)\end{array}$ & $\begin{array}{l}48000 \\
(28.33)\end{array}$ & $\begin{array}{l}56000 \\
(29.68)\end{array}$ & $\begin{array}{l}46311.61 \\
(27.56)\end{array}$ \\
\hline 3. & Machine charges & $\begin{array}{l}5500 \\
(4.62)\end{array}$ & $\begin{array}{l}5500 \\
(3.64)\end{array}$ & $\begin{array}{l}5500 \\
(3.24)\end{array}$ & $\begin{array}{l}5500 \\
(2.91)\end{array}$ & $\begin{array}{l}5500 \\
(3.27)\end{array}$ \\
\hline 3 & Seed cost & $\begin{array}{l}6000 \\
(5.04)\end{array}$ & $\begin{array}{l}7200 \\
(4.77)\end{array}$ & $\begin{array}{l}8400 \\
(4.95)\end{array}$ & $\begin{array}{l}9600 \\
(5.09)\end{array}$ & $\begin{array}{l}8321.813 \\
(4.95)\end{array}$ \\
\hline 4 & Manures & $\begin{array}{l}1800 \\
(1.52)\end{array}$ & $\begin{array}{l}2400 \\
(1.59)\end{array}$ & $\begin{array}{l}2800 \\
(1.65)\end{array}$ & $\begin{array}{l}3200 \\
(1.69)\end{array}$ & $\begin{array}{l}2768.272 \\
(1.65)\end{array}$ \\
\hline 5 & fertilizer & $\begin{array}{l}8400 \\
(7.05)\end{array}$ & $\begin{array}{l}9600 \\
(6.36)\end{array}$ & $\begin{array}{l}10200 \\
(6.02)\end{array}$ & $\begin{array}{l}10000 \\
(5.29)\end{array}$ & $\begin{array}{l}9962.606 \\
(5.93)\end{array}$ \\
\hline 6 & $\begin{array}{l}\text { Plant protection chemical } \\
\text { and herbicide }\end{array}$ & $\begin{array}{l}16580 \\
(13.92)\end{array}$ & $\begin{array}{l}24650 \\
(16.32)\end{array}$ & $\begin{array}{l}32780 \\
(19.34)\end{array}$ & $\begin{array}{l}38000 \\
(20.14)\end{array}$ & $\begin{array}{l}31592.49 \\
(18.80)\end{array}$ \\
\hline 7 & Staking & 0 & 0 & $\begin{array}{l}18000 \\
(10.62)\end{array}$ & $\begin{array}{l}22000 \\
(11.66)\end{array}$ & $\begin{array}{l}17691.22 \\
(10.53)\end{array}$ \\
\hline 8 & Irrigation charges & $\begin{array}{l}1750 \\
(1.47)\end{array}$ & $\begin{array}{l}2200 \\
(1.45)\end{array}$ & $\begin{array}{l}2400 \\
(1.41)\end{array}$ & $\begin{array}{l}2600 \\
(1.38)\end{array}$ & $\begin{array}{l}2379.887 \\
(1.42)\end{array}$ \\
\hline 9 & Interest on working capital & $\begin{array}{l}1280.6 \\
(1.07)\end{array}$ & $\begin{array}{l}2051 \\
(1.35)\end{array}$ & $\begin{array}{l}3073.92 \\
(1.81)\end{array}$ & $\begin{array}{l}2938 \\
(1.56)\end{array}$ & $\begin{array}{l}2751.798 \\
(1.63)\end{array}$ \\
\hline 10 & Total input cost (A) & $\begin{array}{l}99374 \\
(83.48)\end{array}$ & $\begin{array}{l}129205 \\
(85.57)\end{array}$ & $\begin{array}{l}143353.9 \\
(84.62)\end{array}$ & $\begin{array}{l}156238 \\
(82.79)\end{array}$ & $\begin{array}{l}141701.2 \\
(84.33)\end{array}$ \\
\hline 11 & Rental value of land & $\begin{array}{l}18000 \\
(15.12)\end{array}$ & $\begin{array}{l}20000 \\
(13.25)\end{array}$ & $\begin{array}{l}24000 \\
(14.16)\end{array}$ & $\begin{array}{l}30000 \\
(15.89)\end{array}$ & $\begin{array}{l}24292.96 \\
(14.46)\end{array}$ \\
\hline 12 & Land revenue & $\begin{array}{l}12 \\
(0.01)\end{array}$ & $\begin{array}{l}12 \\
(0.0079)\end{array}$ & $\begin{array}{l}12 \\
(0.007)\end{array}$ & $\begin{array}{l}12 \\
(0.0063)\end{array}$ & $\begin{array}{l}12 \\
(0.0071)\end{array}$ \\
\hline 13 & $\begin{array}{l}\text { Depreciation on } \\
\text { implements }\end{array}$ & $\begin{array}{l}416 \\
(0.35)\end{array}$ & $\begin{array}{l}416 \\
(0.27)\end{array}$ & $\begin{array}{l}416 \\
(0.24)\end{array}$ & $\begin{array}{l}416 \\
(0.22)\end{array}$ & $\begin{array}{l}416 \\
(0.247)\end{array}$ \\
\hline 14 & Fixed Cost & $\begin{array}{l}18428 \\
(15.481)\end{array}$ & $\begin{array}{l}20428 \\
(13.52)\end{array}$ & $\begin{array}{l}24428 \\
(14.42)\end{array}$ & $\begin{array}{l}30428 \\
(16.12)\end{array}$ & $\begin{array}{l}24249.29 \\
(14.43)\end{array}$ \\
\hline 15 & Interest on fixed capital & $\begin{array}{l}1228.53 \\
(1.032)\end{array}$ & $\begin{array}{l}1361.867 \\
(0.90)\end{array}$ & $\begin{array}{l}1628.533 \\
(0.96)\end{array}$ & $\begin{array}{l}2028.533 \\
(1.07)\end{array}$ & $\begin{array}{l}1645.153 \\
(0.97)\end{array}$ \\
\hline & Total fixed cost (B) & \begin{tabular}{|l|}
19656.53 \\
$(16.52)$
\end{tabular} & $\begin{array}{l}\mathbf{2 1 7 8 9 . 8 7} \\
(14.43)\end{array}$ & $\begin{array}{l}\mathbf{2 6 0 5 6 . 5 3} \\
(15.38)\end{array}$ & $\begin{array}{l}\mathbf{3 2 4 5 6 . 5 3} \\
(\mathbf{1 7 . 2 0})\end{array}$ & $\begin{array}{l}\mathbf{2 6 3 2 2 . 4 4} \\
(15.66)\end{array}$ \\
\hline & C. Gross $\cos t=(A+B)$ & $\begin{array}{l}119031.1 \\
(100)\end{array}$ & $\begin{array}{l}150994.9 \\
(100)\end{array}$ & $\begin{array}{l}169410.5 \\
(100)\end{array}$ & $\begin{array}{l}188694.5 \\
(100)\end{array}$ & $\begin{array}{l}168023.6 \\
(100)\end{array}$ \\
\hline
\end{tabular}

Note: Figures in the parenthesis are percentage to Gross cost of tomato. 
Table.2 Per ha. yield value of output and cost of production per quintal tomato(In ha)

\begin{tabular}{|l|l|l|l|l|l|l|}
\hline S.No & Particular & \multicolumn{4}{|c|}{ Farm size } \\
\cline { 3 - 7 } & & Marginal & Small & Medium & Large & 0verall \\
\hline $\mathbf{1}$ & Gross Cost(Rs/ha.) & 119031.1 & 150994.9 & 169410.5 & 188694.5 & 168023.6 \\
\hline $\mathbf{2}$ & Yield (qt/ha.) & 314.42 & 426.56 & 496.69 & 586.74 & 466.1025 \\
\hline $\mathbf{3}$ & Price (Rs/qt) & 800 & 800 & 800 & 800 & 800 \\
\hline $\mathbf{4}$ & $\begin{array}{l}\text { Value of Production } \\
\text { (Rs/ha.) }\end{array}$ & 251536 & 341248 & 397352 & 469392 & 372882 \\
\hline $\mathbf{5}$ & $\begin{array}{l}\text { Cost of production } \\
\text { (Rs/qt) }\end{array}$ & 378.5736 & 353.9828 & 341.0789 & 321.5982 & 360.4864 \\
\hline
\end{tabular}

Table.3 Per hectare yield, value of output and cost of production per quintal of Tomato

(Rs/ha)

\begin{tabular}{|c|c|c|c|c|c|c|}
\hline & \multirow[t]{2}{*}{ Particular } & \multicolumn{5}{|c|}{ Farm size } \\
\hline & & Marginal & Small & Medium & Large & Overall \\
\hline 1 & Gross Cost (Rs/ha.) & 119031.1 & 150994.9 & 169410.5 & 188694.5 & 168023.6 \\
\hline 2 & Output value (Rs/qt) & 251536 & 341248 & 397352 & 469392 & 372882 \\
\hline 3 & Net income (Rs) & 132504.9 & 190253.1 & 227941.5 & 280697.5 & 204858.4 \\
\hline 4 & $\begin{array}{l}\text { Family labour } \\
\text { income } \\
\text { (Rs) }\end{array}$ & 184256.35 & 132619.33 & 103880.75 & 69012.022 & 120749.8 \\
\hline 5 & $\begin{array}{l}\text { Farm business } \\
\text { income } \\
\text { (Rs) }\end{array}$ & 185484.9 & 133981.2 & 105509.3 & 71040.52 & 122394.9 \\
\hline 6 & Input -output ratio & $1: 2.5$ & $1: 1.87$ & $1: 62$ & $1: 1.36$ & $1: 1.71$ \\
\hline 7 & $\mathrm{~B}: \mathrm{C}$ & $1: 2.11$ & $1: 2.25$ & $1: 2.34$ & $1: 2.48$ & $1: 2.21$ \\
\hline
\end{tabular}

Table.4 Break-up of total cost, cost concept wise income over different cost in tomato crop

(Rs/ha)

\begin{tabular}{|l|l|l|l|l|l|l|}
\hline S.No & Particular & \multicolumn{5}{|c|}{ Farm size } \\
\cline { 3 - 7 } & & Marginal & Small & Medium & Large & 0verall \\
\hline A & Break-up of cost & & & & \\
\hline & a Cost A & 99374 & 129205 & 143353.9 & 156238 & 141701.2 \\
\hline & b Cost A1 & 117374 & 149205 & 167353.9 & 186238 & 165994.16 \\
\hline & c Cost B & 118602.5 & 150566.9 & 168982.4 & 188266.5 & 167639.3 \\
\hline & d Cost C & 152666.5 & 175170.9 & 181182.4 & 194666.5 & 182060.8 \\
\hline B & Income over different cost & & & & \\
\hline & a Income over cost A & 203484 & 153981.2 & 129509.3 & 101040.5 & 146687.9 \\
\hline & b Income over cost A1 & 185484.9 & 133981.2 & 105509.3 & 71040.52 & 122394.9 \\
\hline & c Income over cost B & 184256.4 & 132619.3 & 103880.8 & 69012.02 & 120749.8 \\
\hline & d Income over cost C & 150192.4 & 108015.3 & 91680.75 & 62612.02 & 106328.3 \\
\hline
\end{tabular}


Cost and returns on the basis of cost concept

The cost and returns based on cost concept in the production tomato on the sample farm of different size groups have been presented in table 4 that on an average Cost A, Cost A1, Cost $\mathrm{B}$ and Cost $\mathrm{C}$ were worked out to be Rs.141701.2, Rs.165994.16, Rs167639.3, and Rs. 182060.8per hectare respectively on the sample farms. The income over different cost were also worked out .The average income over Cost A, Cost A1, Cost B and Cost C were calculated as Rs 146687.9 , Rs 122394.9 , Rs 120749.8, and Rs 106328.3respectively.

Conclusions of the study are as follows:

On an average the cost of cultivation per hectare of tomato was calculated Rs. 1190311.1, Rs.150994.9, Rs. 169410.5 and Rs. 188694.5 respectively marginal, small, medium and large farms.

On an average the input-output ratio of tomato came to $1: 1.71$ respectively on the sample farms.

On an average the $\mathrm{B}: \mathrm{C}$ ratio of tomato came to $1: 2.21$ respectively on the sample farms.

The incomes over different costs were also worked out. The average income over cost-A, cost-B and cost-C were calculated as Rs.146687.9, Rs.120749.8and Rs.106328.3 per hectare, respectively.

\section{References}

Anonymous (2017-18). Directorate of NHM, Department of National Horticulture Mission, Raipur.
Jain, B.C. and Tegar, A. (2003) "Economic of production and marketing of tomato in Jaspur district of Chhattisgarh. Agricultural Marketing. 46(3): 5-10.

Koshta, A.K. and Chandrakar, M.R. (1999) "Economics of production and Marketing of vegetable crops in Durg district of Chhattisgarh region". Agricultural Marketing. 42(2): 28-30.

Kumar, A. 2015.To study different marketing channel, marketing efficiency and problem in vegetable marketing in Varanasi district of Uttar Pradesh. International Journal of Sales and Marketing Management Research and Development, 5:35-44

Ramya, S. I. (2009). Production and Marketing of major vegetable in Bilaspur District. Thesis submitted to department of Agricultural and Natural Resource Economics IGKVV Raipur, Chhattisgarh.

Shende, N.V. and Meshram, R.R. 2015. Cost benefit analysis and marketing of tomato vegetable in Bhandara district. American International Journal of Research in Formal, Applied and Natural Sciences, 11(1):46-54.

Sonawani, M. and Jain, B.C. 2015. Economics of production and marketing of Tomato in Mahasamund district of Chattisgarh. Research Journal of Agril. Sciences, 6:1580-1583.

Ramya, S. I. (2009). Production and Marketing of major vegetable in Bilaspur District. Thesis submitted to department of Agricultural and Natural Resource Economics IGKVV Raipur, Chhattisgarh.

\section{How to cite this article:}

Anjali Verma, B.C. Jain, Shashank Sharma and Yogesh Kumar Sai. 2020. Cost of Cultivation of Tomato Crop in Durg District of Chhattisgarh, India. Int.J.Curr.Microbiol.App.Sci. 9(06): 3406-3410. doi: https://doi.org/10.20546/ijcmas.2020.906.403 